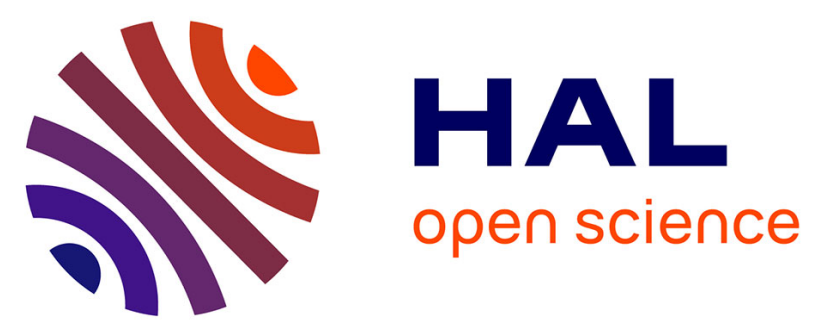

\title{
Hair mercury levels in relation to fish consumption in a community of the Moroccan Mediterranean coast
}

Hecham Elhamri, Larbi Idrissi, Marina Coquery, Sabine Azemard, Abdellah Elabidi, Mohamed Benlemlih, Mohamed Saghi, Francesco Cubadda

\section{- To cite this version:}

Hecham Elhamri, Larbi Idrissi, Marina Coquery, Sabine Azemard, Abdellah Elabidi, et al.. Hair mercury levels in relation to fish consumption in a community of the Moroccan Mediterranean coast. Food Additives and Contaminants, 2007, 24 (11), pp.1236-1246. 10.1080/02652030701329611. hal00577451

\section{HAL Id: hal-00577451 \\ https://hal.science/hal-00577451}

Submitted on 17 Mar 2011

HAL is a multi-disciplinary open access archive for the deposit and dissemination of scientific research documents, whether they are published or not. The documents may come from teaching and research institutions in France or abroad, or from public or private research centers.
L'archive ouverte pluridisciplinaire HAL, est destinée au dépôt et à la diffusion de documents scientifiques de niveau recherche, publiés ou non, émanant des établissements d'enseignement et de recherche français ou étrangers, des laboratoires publics ou privés. 


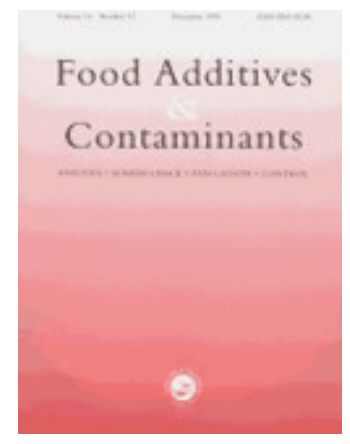

\section{Hair mercury levels in relation to fish consumption in a community of the Moroccan Mediterranean coast}

\begin{tabular}{|r|l|}
\hline Journal: & Food Additives and Contaminants \\
\hline Manuscript ID: & TFAC-2006-347.R1 \\
\hline Manuscript Type: & Original Research Paper \\
\hline Author: & 05-Mar-2007 \\
\hline Complete List of Authors: & $\begin{array}{l}\text { Elhamri, Hecham; National Institute of Health, Departement of } \\
\text { Toxicology } \\
\text { Idrissi, Larbi; National Institute of Health, Departement of } \\
\text { Toxicology } \\
\text { Coquery, Marina; CEMAGREF, Département Milieux aquatiques } \\
\text { Azemard, Sabine; IAEA, Marine Environnent Laboratory } \\
\text { Elabidi, Abdellah; National Institute of Health, Departement of } \\
\text { Toxicology } \\
\text { Benlemlih, Mohamed; Faculty of Science Dhar El Mahrez, } \\
\text { Laboratory of Environmental Microbiology } \\
\text { Saghi, Mohamed; University Mohamed V, Laboratory of Pollution, } \\
\text { Ecotoxicology and Sanitary Risk } \\
\text { Cubadda, Francesco; Istituto Superiore di Sanità, National Centre } \\
\text { for Food Quality and Risk Assessment }\end{array}$ \\
\hline Methods/Techniques: & AAS, Exposure assessment, Health significance, Regression \\
\hline Additives/Contaminants: & Heavy metals - mercury \\
\hline Food Types: & Fish \\
\hline
\end{tabular}

\section{SCHOLARONE" Manuscripts}




\section{Hair mercury levels in relation to fish consumption in a 2 community of the Moroccan Mediterranean coast}

3 Hecham Elhamri ${ }^{\mathbf{1}}$, Larbi Idrissi ${ }^{\mathbf{1}}$, Marina Coquery $^{\mathbf{2}}$, Sabine Azemard ${ }^{\mathbf{3}}$, Abdellah Elabidi ${ }^{\mathbf{1}}$, Mohamed Benlemlih ${ }^{4}$, Mohamed Saghi ${ }^{5}$, Francesco Cubadda ${ }^{6} *$

${ }^{1}$ Department of Toxicology, National Institute of Health, PO Box 769, Agdal, Rabat, Morocco

2 CEMAGREF, Groupement de Lyon, Département Milieux aquatiques, 3bis, quai

0 Chauveau, CP 220, 69336 Lyon cedex 09, France

13 IAEA, Marine Environnent Laboratory, 4 quai Antoine $1^{\mathrm{er}}$, MC 98000, Monaco

24 Laboratory of Environmental Microbiology, Faculty of Science Dhar El Mahrez, P.O Box 3 1796, Fes, Morocco

$4{ }^{5}$ Laboratory of Pollution, Ecotoxicology and Sanitary Risk, Scientific institute, University

5 Mohamed V, P.O Box 703, Rabat, Morocco

${ }^{6}$ National Centre for Food Quality and Risk Assessment, Istituto Superiore di Sanità, Viale 17 Regina Elena 299, 00161 Rome, Italy

\section{Abstract}

21 Coastal populations with high seafood consumption in the Mediterranean have a significant 22 exposure to dietary methylmercury and areas where environmental mercury pollution is an 23 issue due to industrial activities are of special concern. The present study was undertaken with 24 the aim of assessing methylmercury exposure through fish consumption in a community of 25 north Morocco and characterizing the relevant health risk. Concentrations of total mercury 26 were determined in human hair, a biomarker of methylmercury exposure, and in locally 27 consumed fish by cold vapour atomic absorption spectrophotometry. Based on consumption 
1 frequencies reported by the 108 subjects included in the study the weekly intake of

2 methylmercury was estimated and biomarker data were evaluated in relation to the estimated

3 intake and the sociodemographic characteristics of the population. Multiple regression

4 analysis was employed for interpretation of hair mercury data in relation to fish consumption

5 frequency, gender and age of individuals. Mercury concentrations in hair ranged from 0.22 to

$6 \quad 9.56 \mu \mathrm{g} / \mathrm{g}$ (geometric mean $1.79 \mu \mathrm{g} / \mathrm{g}$ ) and were closely related to fish intake. Fisherman and

7 their families consumed fish 3-5 times per week and were the most exposed population

8 subgroup. A high proportion of women of childbearing age (50\%) had relatively high levels

9 of mercury in their hair $(3.08-7.88 \mu \mathrm{g} / \mathrm{g})$.

10 Keywords: Mercury, Hair, Fish, Multiple regression analysis, Weekly intake, Biomarkers of 11 exposure, Exposure assessment, Risk characterization, Morocco, Mediterranean Sea.

\section{Introduction}

13 Environmental mercury levels have increased considerably since the on-set of the 14 industrial age. Even regions with no significant mercury releases, such as the Arctic, appear to 15 be affected due to the transcontinental and global transport of mercury (Muir et al. 1999; 16 AMAP 1998). Elemental or inorganic mercury released into the air or water becomes 17 methylated in the aquatic environment where it accumulates in animal tissues and increases in 18 concentration through the food chain (WHO 1990). As a result of bioaccumulation in the 19 aquatic food chain, fish contain the highest levels of mercury, largely as methylmercury. Food 20 sources other than fish and seafood products generally contain low concentrations of mercury, 21 mostly in the form of inorganic mercury. Based on the available data the contribution to 22 methylmercury exposure from these foods is considered to be insignificant. Mercury toxicity 23 depends on its speciation and inorganic mercury is considerably less toxic than 24 methylmercury. Methylmercury is highly toxic particularly to the nervous system, and the 
1 developing brain is thought to be the most sensitive target organ for methylmercury toxicity

2 (WHO 1990). Based on the outcome of large epidemiological studies of fetal neurotoxicity in

3 fish-eating population of the Seychelles, the Faroes Islands and New Zealand, several national

4 and international bodies have revised their health based guidance values for methylmercury 5 (EFSA 2004). On the other hand, non-neurological risks for adults associated with 6 methylmercury, including the potential for adverse cardiac outcomes, have not yet been 7 incorporated into risk assessments.

9 Total mercury concentration in hair is a reliable marker of methylmercury exposure through 10 fish consumption (Berglund et al. 2005). Compared to blood, hair is easier to collect and 11 analysis is easier to carry out due to the comparatively high mercury content (Airey 1983). 12 Determination of total mercury is more straightforward than that of methylmercury and this 13 allows extensive human monitoring to be done at reasonable costs. Moreover, each $\mathrm{cm}$ of hair 14 approximately represents one-month exposure so that a time record of previous mercury 15 exposure can be established for a subject depending on the hair length.

17 The Mediterranean region is located on a mercuriferous belt that extends itself until central 18 Asia and has been interested by intensive mercury mining of cinnabar deposits since ancient 19 times (Hylander and Meili 2003). Mobilization of mercury has lead to an increase of the 20 concentrations of this element in water bodies, the atmosphere and all of the environmental 21 compartments. Mercury emissions to the atmosphere from natural sources are an important 22 element of the biogeochemical cycle of mercury (Working group on mercury 2001). 23 Volatilisation of elemental mercury from surface waters and emissions from volcanoes in the 24 Mediterranean region represents a significant contribution to the total mercury budget 25 released in Europe and to the global atmosphere (Pirrone et al. 2001). Recent measurements 
1 of dissolved gaseous mercury suggested the existence of a gradient with higher concentrations

2 in the eastern sector of the Mediterranean with respect to the western sector (Gårdfeldt et al.

3 2003). Natural abundance of mercury in the Mediterranean, a sea with a very slow water

4 turnover, has raised the question of the potential impact on marine food chains 5 (UNEP/FAO/WHO 1987). According to some authors, there is evidence that marine 6 organisms living in this basin have higher mercury body burdens than the same (or similar) 7 species in the Atlantic and other Oceans (Renzoni et al. 1998).

9 Apart from natural sources and mining, mercury has been extensively used in many products 10 and industrial processes, with chlor-alkali production among the largest international uses of 11 mercury in the world (Hylander and Meili 2003). In one of the common processes for chlor12 alkali production - the mercury cell process - large quantities of mercury serve as a liquid 13 cathode in electrolytic cells. The process releases mercury to the environment with both air 14 emissions and water discharges, and mercury-containing solid and liquid wastes are 15 generated. Today, emission controls and conversion to non-mercury technologies have led to 16 a steady decrease in the consumption and releases of mercury in this industrial sector.

18 The small town of Martil in the Tetouan province is a harbour located on the Moroccan 19 Mediterranean coast $\left(35^{\circ} 37^{\prime} \mathrm{N}, 5^{\circ} 17^{\prime} \mathrm{W}\right)$. Several industrial plants, including one for chlorine 20 and caustic soda production employing the mercury cell technology, are located in the area. 21 As a result, mercury is released into the surrounding environment, mainly in the form of solid 22 and liquid wastes (ca. $15 \mathrm{~g} \mathrm{Hg} / \mathrm{kg}$ dry matter) (Bryler-Iskane-Sheladia 1994). The extent of 23 mercury contamination of the marine environment and its resources is actually an issue of 24 importance due to fishing activities in this area and potential human exposure. 
1 The present investigation was undertaken with the aim of assessing the exposure of the local

2 population to mercury through fish consumption and characterizing the relevant health risk.

3 For this purpose, the occurrence of mercury in seafood was studied and the mercury human

4 intake through fish consumption calculated. Hair was used as the biomarker of exposure and

5 the focus of this paper is mainly on the relationship between hair mercury and fish

6 consumption as well as the effect of other factors such as gender and age of individuals.

7 Multiple regression analysis was employed for interpretation of hair mercury data in relation

8 to the different independent variables.

\section{$9 \quad$ Materials and Methods}

$10 \quad$ Subjects and biomarker assessment

11 Hair samples were collected from 108 individuals (68 males, 40 females) living in Martil 12 from April to June 2001. The study area is shown in Figure 1. Each subject was asked to 13 complete a brief questionnaire detailing age, profession, fish species consumed, and fish 14 consumption frequency (FCF) expressed as times per week. As far as possible, a random 15 sample of the non-institutionalized civilian population of the study area was surveyed. People 16 occupationally exposed to mercury (e.g. workers in chloral-alkali plants) were not included in 17 the survey. Sociodemographic data are summarized in Table I.

19 Hair samples (length $=c a 2 \mathrm{~cm}$ ) were cut from the occipital region of the scalp. Since hair 20 treatments (e.g., bleaching, dyeing, artificial waving) may influence the mercury content of 21 hair strands, only untreated hair was selected for the study. None of the surveyed subjects had 22 dental amalgam fillings, a possible source of elemental mercury. Hair specimens were packed 23 in polyethylene bags and stored at room temperature until analysis. 


\section{$1 \quad$ Fish sampling and treatment}

2 Based on information in the questionnaires, the most commonly consumed fish were pilchard

3 (Sardina pilchardus W., Clupeidae), common mullet (Mugil cephalus L., Mugilidae), and

4 hake (Merluccius merluccius L., Merlucciidae). Altogether about seventy samples of these

5 three species were collected between September 2000 and July 2001 in the fishing area shown

6 in Figure 1 and stored frozen in polyethylene bags pending analysis. Fillet was excised from

7 the left dorsal muscle and submitted to both dry weight determination and mercury

8 measurements. For the sake of comparison with literature values, mercury concentrations are

9 expressed hereafter on a fresh weight $(f w)$ basis. Data can be converted to a dry weight $(d w)$

10 basis using $d w / f w$ ratios of 0.38 for pilchard, 0.24 for common mullet, and 0.18 for hake.

12

13

14

15

\section{Mercury determination}

Hair sub-samples of approximately $300 \mathrm{mg}$ were dried at $30^{\circ} \mathrm{C}$ for $24 \mathrm{~h}$ and then digested with $4 \mathrm{ml}$ of concentrated nitric acid and $2 \mathrm{ml}$ of concentrated sulfuric acid (Suprapur, Merck, Darmstadt, Germany). Both acids had negligible levels of $\mathrm{Hg}$ impurities. After digestion $\left(90^{\circ} \mathrm{C}, 4 \mathrm{~h}\right)$, the analytical solutions were allowed to cool down and were diluted to $50 \mathrm{ml}$ with $\mathrm{K}_{2} \mathrm{Cr}_{2} \mathrm{O}_{7}(1 \mathrm{ml})$ and deionized water obtained from a Milli-Q system (Millipore, Molsheim, France). The same procedure was adopted for fish samples, but in this case subsamples of about $1 \mathrm{~g} f w$ were digested.

Mercury was determined by cold vapour atomic absorption spectrophotometry using a Varian Spectra AA20 equipped with a VGA-76 hydride generator. A stannous chloride solution was used to reduce $\mathrm{Hg}$ to the elemental form. 
1 The quality control procedures included analysis of two reference materials (RMs), i.e. 2 unspiked human hair (IAEA-086) and fish muscle (IAEA-407), both from the IAEA-MEL 3 (Monaco). These RMs were regularly included in the analytical batches throughout the

4 survey. The result of 14 independent replicate determinations of IAEA-086 was $0.59 \pm 0.03$ $5 \mu \mathrm{g} / \mathrm{g} d w$ (mean \pm S.D.), compared to a target value of $0.573 \mu \mathrm{g} / \mathrm{g} d w$ with a $95 \%$ confidence 6 interval $(\mathrm{CI})$ of $0.534-0.612 \mu \mathrm{g} / \mathrm{g} d w$. The found value for IAEA-407 was $0.213 \pm 0.019 \mu \mathrm{g} / \mathrm{g}$ $7 d w$, compared to a recommended value of 0.222 with a $95 \%$ CI of $0.216-0.228 \mu \mathrm{g} / \mathrm{g} d w$. 8 Duplicate analyses were carried out throughout the study and the precision was always better 9 than $5 \%$. The method detection limit was $0.05 \mu \mathrm{g} / \mathrm{g} d w$ based on a sample weight of $0.5 \mathrm{~g}$.

11 Analytical determinations were carried out at the Marine Environment Laboratory (IAEA, 12 Monaco) and at the Department of Toxicology (National Institute of Health, Morocco).

14 Statistical Analysis

15 Mercury concentrations expressed on a $f w$ basis were employed in all calculations. 16 Distributions, extreme hair mercury values and correlations between variables were examined 17 initially. After the initial analyses demonstrated that the hair mercury data were non-normally 18 distributed, a logarithmic transformation was applied to normalize the distribution of data. 19 Box plots, normal probability plots, and residual analysis were used to search for possible 20 outliers; however it was not deemed necessary to eliminate any of the log-transformed values. 21 Arithmetic means (AMs), geometric means (GMs), percentiles were calculated for the whole 22 population sample and for several sub-groups identified on the basis of gender, age or FCF. In 23 the comparisons between groups one-way ANOVA and ANCOVA on log-transformed data 24 were used. Tests of statistical significance used a $p$ value of 0.05 . 
1 The relationship between hair mercury and fish consumption as well as the effect of various

2 independent variables that possibly influenced $\mathrm{Hg}$ concentrations were studied by multiple

3 regression analysis. When age was included in regression models as an independent variable,

4 five sub-groups were considered (i.e. 10-19, 20-29, 30-39, 40-49, >50 years). In all of the

5 regression analyses $y^{\prime}=\log _{10}(y+1)$, where $y$ is the hair mercury concentration, was the

6 dependent variable. Residual analysis showed that the logarithmic transformation

7 substantially reduced deviations of the original dataset from normality, homoscedasticity and

8 other assumptions of the linear regression model.

9

10 Statistical analyses were performed using Statistica (version 7.0, StatSoft, Inc.) and SPSS 11 (version 13.0, SPSS Inc.).

\section{Results and Discussion}

13

\section{Mercury in Hair}

Table II summarizes descriptive statistics concerning mercury concentrations in hair. Fish consumption was firstly investigated as the most important predictor of hair mercury levels. In the population sample under study, the average weekly consumption of fish ranged from 0 to 5 times per week with an $\mathrm{AM}$ of 2.2 times per week (males 2.5, females 1.7 times per week). Nearly all subjects (96\%) were fish consumers and 36\% can be regarded as heavy consumers (consumption frequency of 3-5 times per week).

The original (untransformed) dataset of hair mercury concentrations is plotted in Figure 2 against FCF. It is clear that the relationship between the two variables in non-linear, as exemplified by a first order and a second order polynomial fit in Figure 2. As data deviated from the normal distribution required for the application of parametric statistics, a logarithmic 
1 transformation of the independent variable was applied. Log-transformed data showed a linear

2 relationship to FCF according to the equation:

$$
y^{\prime}=0.059+0.199 x
$$

4 with $\mathrm{R}=0.929$ and $p<0.001$ ('model 1' in Table III).

The influence of gender and age was then considered and both factors were found to be

7 significantly related to the independent variable ('model 2', Table III). In the population

8 sample under study male subjects had higher concentrations in their hair due to higher FCFs.

9 When data were stratified for fish consumption, females averaged higher mercury 10 concentrations in their hair. This outcome might either be related to some specific 11 characteristics of the studied population or reflect a general pattern, e.g. differences in 12 physiology or metabolism. Higher levels of hair mercury in females than in males have been 13 found in several other studies (Benson and Gabica 1972, Sumino et al. 1975, Bulinski et al. 14 1979, Batista et al. 1996, Pellizzari et al. 1999, Babi et al. 2000, Agusa et al. 2005), 15 notwithstanding the general belief that male subjects exhibit a greater tendency to mercury 16 accumulation in their hair. However, failure to take into account the effect of fish 17 consumption (with stratification for FCF) and of possible other confounders (see Airey, 1983) 18 might have biased the results of most of the studies that investigated gender-specific 19 differences in hair mercury, so that no definitive conclusion can be drawn. Some authors also 20 found that gender is an insignificant factor for any form of mercury accumulation in hair 21 (Suzuki et al. 1976).

23 The effect of age on hair mercury is shown in Figure 3 for a selected population sub-group, 24 i.e. those with a FCF of 1 time per week. Figure 3 shows that mercury levels had a small 25 variability in females whereas in males a distinct trend towards a greater accumulation with 
1 increasing ages was evident up to the age of 50 years. Thus separate regression models were

2 developed for males and females. As expected, age was a significant predictor of hair mercury

3 only in the case of male subjects ('model 3', Table III) whereas for females FCF was the only

4 independent variable acting on hair mercury ('model 4', Table III). A similar result was

5 obtained in studies of population groups in Cambodia and South Korea (Agusa et al. 2005;

6 Lee and Lee 1999). In particular, Lee and Lee (1999) reported that hair mercury levels of

7 Korean male subjects were significantly different according to their occupation and age 8 groups, but in females such variation was not detectable.

9

The dependence of hair mercury on age is possibly due to the greater fish consumption in 11 males, which results in an input rate higher than the mercury excretion rate with consequent 12 age-related accumulation. Twenty out of thirty subjects with hair mercury contents above 4 $13 \mu \mathrm{g} / \mathrm{g}$ were males, typically fishermen, with a FCF of 3-5 times per week. The hair content of 14 these thirty subjects exerted a great influence on the shape of the experimental plot as shown 15 in Figure 2. On the other hand age-related accumulation in males could be at least partially 16 due to other sources of exposure, outside the household, not accounted for by the present 17 study and possibly related to occupation and/or some specific habits (e.g. smoking).

A positive relationship between hair mercury levels and age has been reported by several 20 authors (Paccagnella et al. 1973, Sivalingam and Binti Sani 1980, Nakagawa 1995, Dickman 21 et al. 1998, Dumont et al. 1998, Pellizzari et al. 1999). Generally hair mercury has been found 22 to increase up to a given age, which changes depending on the population studied, and then 23 gradually decrease. This trend is consistent with that of subjects aged $>50$ years in this study, 24 i.e. almost constant levels of hair mercury in males and a decrease in females (not statistically 25 significant). 
2 Table IV shows the results of mercury determination in muscle tissue of the most widely

3 consumed fish in the Martil area. These concentration values can be compared with

4 background concentrations for the same species in the Mediterranean. In doing this, attention

5 has to be paid to the size of organisms, as mercury accumulation in fish is generally an age-

6 related process.

7

8 Pilchards of a standard length of $15 \mathrm{~cm}$ from non-contaminated Mediterranean environments 9 generally have mercury concentrations in the range 0.08-0.12 $\mu \mathrm{g} / \mathrm{g}$ (Del Prete e Bolletta 1984;

Buzina et al. 1989; Thibaud and Noel 1991; Pastor et al. 1994; Serrano et al. 1994; Bolletta 1996; Joiris et al. 1999; Storelli et al. 2003). Specimens from the study area had a length range of 10-14 $\mathrm{cm}$ and a mean mercury concentration of $0.137 \mu \mathrm{g} / \mathrm{g}$. In the case of common mullet background concentrations for commonly exploited sizes (about $25 \mathrm{~cm}$ ) are in the range 0.05-0.09 $\mu \mathrm{g} / \mathrm{g}$. (Del Prete and Bolletta 1984; Crisetig et al. 1985; Focardi et al. 1991; Cubadda et al. unpublished results), whereas in the study area individuals of this species had a length range of $20-25 \mathrm{~cm}$ and a mean concentrations of $0.096 \mu \mathrm{g} / \mathrm{g}$.

Comparison is less easily done in the case of hake because of the large spread of values found in the literature, which is possibly due to the age-related changes in habitat and feeding habits exhibited by this species. Juveniles are found in deep waters and feed on crustaceans (especially euphausiids and amphipods), whereas adults move to coastal waters and mainly feed on fish (including pilchard) and squids (Froese and Pauly 2006). This means that adult individuals are most prone to mercury (and especially methylmercury) accumulation due to their higher trophic level and preference for coastal environments, i.e., areas where mercury contamination is more likely to occur. A realistic range of typical concentrations equal to 
$1 \quad 0.10-0.25 \mu \mathrm{g} / \mathrm{g}$ can be estimated for specimens of $25-35 \mathrm{~cm}$ body length (Del Prete and

2 Bolletta 1984; Horvat et al. 1989; Mikac e Picer 1985; Cannizzaro et al. 1986; Capelli et al.

3 1991; Vukadin et al. 1995; Bolletta 1996; Capelli et al. 2004; Storelli et al. 2005). In the study

4 area hake specimens were for the most part of smaller size, nevertheless the mean mercury

5 concentration was $0.101 \mu \mathrm{g} / \mathrm{g}$ with a maximum of $0.124 \mu \mathrm{g} / \mathrm{g}$.

6

7 Overall, these data are indicative of mercury environmental concentrations slightly above

8 Mediterranean background levels in the Martil fishing area. However, none of the fish

9 specimens analysed exceeded the maximum limit of $0.50 \mu \mathrm{g} / \mathrm{g}$ established by the relevant EU

10 regulation.

\section{Exposure assessment}

12 The GM of the hair mercury content of subjects who did not consume fish was $0.29 \mu \mathrm{g} / \mathrm{g}$, 13 whereas the least-square value obtained from the y-intercept of the regression line was 0.15 $14 \mu \mathrm{g} / \mathrm{g}$. These values reflect average background mercury exposures resulting from sources 15 other than fish consumption, i.e. other foods and non-dietary sources. They are in good 16 agreement with those reported for populations with no or marginal fish consumption in 17 Sweden (0.04-0.32 $\mu \mathrm{g} / \mathrm{g}$, Lindberg et al. 2004), USA (0.29 $\mu \mathrm{g} / \mathrm{g}$, Pellizzari et al. 1999), Hong

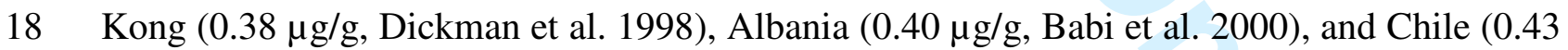
$19 \mu \mathrm{g} / \mathrm{g}$, Bruhn 1994).

21 The weekly intake of mercury as a function of FCF was estimated for the target population on 22 the basis of concentration data in fish. As discussed above, the mercury content of commonly 23 consumed fishes was similar on a $f w$ basis and thus data were averaged for the purpose of 24 intake estimation. Based on local uses, a fish serving amounts to about $200 \mathrm{~g}$ and this average figure was used in calculations. Methylmercury intake was estimated assuming that $90 \%$ of 
1 mercury in fish is in the monomethylated form. The results are shown in Table $\mathrm{V}$ along with

2 the corresponding mercury concentrations in hair. The latter were compared with those

3 calculated by means of two simple models developed by WHO. Both assume a linear

4 relationship between methylmercury intake and blood concentration of mercury at steady

5 state, with subsequent conversion of blood concentrations to hair concentrations using a

6 blood-to-hair ratio of 250. According to the first model, an intake of $1 \mu \mathrm{g}$ of mercury per $\mathrm{kg}$

7 body weight per week in the form of methylmercury corresponds to a concentration of $10 \mu \mathrm{g}$

$8 \mathrm{Hg} / \mathrm{L}$ of blood and $2.5 \mathrm{mg} \mathrm{Hg} / \mathrm{kg}$ of hair (WHO 2000). Alternatively, the quantitative

9 relationship between exposure (intake) and concentration in hair can be expressed in a more 10 meaningful way by means of a toxicokinetic model in the form of the following equation 11 (adapted from WHO 1990):

$$
C=\frac{d \times A \times f \times R}{b \times V \times 10^{3}}
$$

13 where:

$14 C$ is the concentration of mercury in hair in $\mu \mathrm{g} / \mathrm{g}$,

$15 d$ is the daily dietary intake of methylmercury in $\mu \mathrm{g}$,

$16 A$ is the fraction of methylmercury in the diet that is absorbed,

$17 f$ is the fraction of absorbed methylmercury that is found in the blood,

$18 R$ is the ratio of the concentration in hair (in $\mu \mathrm{g} / \mathrm{g}$ ) to that in blood $(\mu \mathrm{g} / \mathrm{L})$,

$19 b$ is the elimination constant,

$20 \quad V$ is the blood volume in the body in $\mathrm{L}$.

The hair mercury concentrations calculated by means of the first model (assuming a body 23 weight of $60 \mathrm{~kg}$ ) and the second model (assuming $A=0.95, f=0.05, R=250, b=0.01, V=$ 244.2 ) were 0.83 and $0.81 \mu \mathrm{g} / \mathrm{g}$, respectively, for a consumption frequency of 1 fish meal per 25 week (weekly methylmercury intake $=20 \mu \mathrm{g}$ ), and 1.67 and $1.62 \mu \mathrm{g} / \mathrm{g}$, respectively, for a 
1 consumption frequency of 2 fish meals per week (weekly methylmercury intake $=40 \mu \mathrm{g}$ ).

2 These figures agree closely with those reported in Table V. For consumption frequencies $\geq 3$,

3 the calculated concentrations deviate substantially from the observed ones. WHO algorithms

4 are based on single-compartment models and assume constant steady state blood-to-intake

5 and blood-to-hair ratios. In the studied population this simple approach appears to be

6 inadequate for the description of mercury biokinetics in heavy fish consumers, which resulted

7 in a non-linear relationship between intakes and hair mercury levels (Figure 2).

8

9 Hair has been used as the biomarker of mercury exposure in several studies carried out in the

Mediterranean region; those published since 1995 are summarized in Table VI. Comparisons with concentration levels found in other studies should be carried out with caution due to differences in study design, sampling strategies, and the existence of several confounding factors. For instance, repetitive seasonal changes in diet and metabolism cause a yearly pattern in the amount of mercury excreted into the hair and this lead to a bias that is rarely accounted for when such comparisons are made. Bearing in mind that several potential confounders may exist, nevertheless it can be observed that hair concentration values obtained in this study were higher than those obtained in the largest study carried out so far in the area (Belloni et al. 1998), when adjusted for the estimated weekly fish consumption of the various population groups. Mercury levels in women's hair were lower than those found by Gibicar et al. (2006) in a mercury-rich area of the Aegean sea when subjects with a FCF of 0-1 times per week are considered, and higher for FCFs $\geq 2$. Levels in children aged 10-16 were similar to that found by Batista et al. (1996) when adjusted for FCFs. In general, mercury levels in childrens hair in this study were lower than those of adults for both sexes when adjusted for FCFs $(p<0.001)$. 
1 The highest levels of mercury recorded in this study (about $9.5 \mu \mathrm{g} / \mathrm{g}$ ) were found in the hair

2 from people who had a FCF of 5 times per week and lived near the Martil estuary, which is

3 located $4 \mathrm{~km}$ downstream the plant for chlorine and caustic soda production. It is possible that

4 these individuals had higher-than-estimated intakes due to fishing in an area influenced by a

5 hot spot of mercury contamination. The fish samples collected for this study were meant to

6 determine an exposure estimate for the entire community and not to address extreme

7 exposures due to preferential fishing in highly contaminated areas. In the literature, maximum

8 levels far above $10 \mu \mathrm{g} / \mathrm{g}$ have been reported for several populations (Table VI), but they

9 typically refer to people with FCFs $\geq 7$ times per week.

11 Risk Characterization

12 In 2003 the Joint FAO/WHO Expert Committee on Food Additives (JECFA) revised the 13 Provisional Tolerable Weekly Intake (PTWI) for methylmercury to $1.6 \mu \mathrm{g} / \mathrm{kg}$ body weight, 14 whereas it was previously $3.3 \mu \mathrm{g} / \mathrm{kg}$ body weight, based on the epidemiological studies in the 15 Faroe Islands and the Seychelles that investigated the relationship between maternal exposure 16 to mercury and impaired neurodevelopment in their children (WHO 2004). For a person with 17 a body weight of $60 \mathrm{~kg}$ the PTWI is equal to $96 \mu \mathrm{g}$, a level that in the target population is 18 slightly exceeded by the consumers with a FCF of 5 times per week (estimated weekly intake $19=100 \mu \mathrm{g}$ ). However it should be noticed that in our population sample no women reported a 20 FCF above 4 times per week.

22 JECFA used the average from the two above-mentioned studies, $14 \mu \mathrm{g} / \mathrm{g}$ maternal hair23 mercury, as an estimate of the concentration of methylmercury in maternal hair that reflects 24 exposures that would have no appreciable adverse effect on the offspring. Concentration in 25 hair was converted into maternal methylmercury intake using the one-compartment model and 
1 steady state blood-to-hair and blood-to-intake ratios. A total uncertainty factor (UF) of 6.4

2 was applied to derive a PTWI that was considered sufficient to protect developing fetuses, the

3 most sensitive subgroup of the population. Application of the same UF to hair mercury would

4 give a concentration of $2.2 \mu \mathrm{g} / \mathrm{g}$.

6 In our population sample the maximum mercury concentration in hair was 9.56 (male 7 subject), but the GM of hair mercury concentrations of women aged 18-45 years was 2.05 $8 \mu \mathrm{g} / \mathrm{g}$ and the $95 \%$ percentile was $6.83 \mu \mathrm{g} / \mathrm{g}$. If the subgroup of women aged $20-40$ years is 9 considered, the GM of hair concentrations was $2.44 \mu \mathrm{g} / \mathrm{g}$ and the $95 \%$ percentile was 7.16 $10 \mu \mathrm{g} / \mathrm{g}$. Fishermen's wives aged 20-40 years are clearly the population subgroup that deserve 11 the highest attention due to average FCFs of 4 times per week and hair mercury 12 concentrations $(\mathrm{GM})$ of $6.51 \mu \mathrm{g} / \mathrm{g}($ range $=5.42-7.88 \mu \mathrm{g} / \mathrm{g})$.

14 In carrying out any risk characterization it should be kept in mind that health based guidance 15 values are based on several assumptions, each associated with some degree of uncertainty. In 16 fact, using a different approach and different UFs, the US Environmental Protection Agency 17 (EPA) and US National Research Council (NRC) established a reference dose (RfD) of 0.1 $18 \mu \mathrm{g} / \mathrm{g}$ body weight per day or $0.7 \mu \mathrm{g} / \mathrm{g}$ body weight per week ( $42 \mu \mathrm{g} /$ week for a body weight of $1960 \mathrm{~kg}$ ), which corresponds to a hair mercury level of about $1 \mu \mathrm{g} / \mathrm{g}$ (NRC 2000).

21 As a further complication, it should be also noticed that ethnic factors might possibly exert an 22 influence on dose-response relationships and steady state biomarker ratios used in the 23 evaluations. This is particularly true in regard to the use of hair as a biomarker of exposure. 24 Based on structural differences, hair is usually categorized into three ethnic groups (African, 25 Asian, and Caucasian) (Wolfram 2003). As noted by Budtz-Jorgensen et al. (2004), available 
1 information suggests that Asian and Caucasian hair, although structurally different, is quite

2 similar in regard to the mercury hair-to blood ratio, but African hair, although extensively 3 studied, has not yet been calibrated in regard to methylmercury intake and blood 4 concentration.

\section{Conclusions}

6 This is the first published study on the exposure of Moroccan population to mercury through 7 fish consumption. The establishment of baseline levels for the study area enables future 8 monitoring to be carried out with the aim to detect changes in (methyl)mercury exposure, 9 especially in relation to the impact of industrial and other human activities on the marine 10 ecosystem.

12 Based on the combined evidence gained through dietary intake estimation and use of hair as 13 the biomarker of exposure it appeared that only a few among fishermen (and possibly their 14 relatives) were likely to exceed the JECFA PTWI regularly, but on the other hand about 50\% 15 of women aged 18-45 years had hair mercury concentrations above $2.2 \mu \mathrm{g} / \mathrm{g}$. On the whole, 16 the present results indicate a narrow margin of safety for a sizeable part of the adult 17 population including many women of childbearing age and support efforts to reduce 18 methylmercury exposure.

20 Fish and seafood products are important sources of energy, protein, and a variety of essential 21 nutrients, such as vitamins, trace elements, and omega-3 fatty acids. Because of the beneficial 22 effects of fish consumption, the long-term aim would not be to reduce fish intake in the Martil 23 community, but to develop advisories for heavy consumers on recommended fish species with 24 low methylmercury content and to reduce mercury emissions in the environment resulting from human activities. 
2 The mercury content of fish from the study area was indicative of mercury environmental

3 concentrations slightly above Mediterranean background levels. However it cannot be

4 excluded that fishing resources directly impacted from point sources of mercury emissions

5 had higher contamination levels and were nevertheless exploited by a part of the fishing

6 community in the study area. Mercury releases from chlor-alkali operations can be either

7 substantially reduced by installation of proper devices/techniques for removal of mercury at

8 points of emission generation or entirely eliminated by converting to a mercury-free process

9 such as the membrane process - a more energy efficient technology indeed - as already

10 happened in most of the industrialized countries. In the interest of health protection of these

11 fishing communities, a substantial reduction of mercury releases from chlor-alkali and other

12 industrial facilities would represent an important step forward.

\section{Acknowledgments}

14 The authors thank Dr. Benajiba Abdelawahab and Dr. Fekhaoui Mohamed for excellent

15 technical assistance. The cooperation of Barakate Nezha, Sadeq Amina, Rhadhioui Nabiha,

16 Walid Myriam, Nouari Naima, Benaami Fatima, Azizi Rokya, Brini Farida, Benbakhta

17 Bouchaib, Benaakam Rachid, and Benaabou El Bachir is also gratefully acknowledged.

\section{References}

19 Agusa T, Kunito T, Iwata H, Monirith I, Tana TS, Subramanian A, Tanabe S. 2005. Mercury 20 contamination in human hair and fish from Cambodia: levels, specific accumulation and risk 21 assessment. Environmental Pollution 134:79-86.

22 Airey D. 1983. Mercury in human hair due to environment and diet: a review. Environmental 23 Health Perspectives 52:303-316. 
1 AMAP. 1998. AMAP Assessment Report: Arctic Pollution Issues. Oslo: Arctic Monitoring 2 and Assessment Programme (AMAP). p 859

3 Babi D, Vasjari M, Celo V, Koroveshi M. 2000. Some results on Hg content in hair in 4 different populations in Albania. The Science of the Total Environment 259:55-60.

5 Batista J, Schuhmacher M, Domingo JL, Corbella J. 1996. Mercury in hair for a child 6 population from Tarragona Province, Spain. The Science of the Total Environment 193:1437148.

8 Belloni P, Ingrao G, Bertone A, Gambelli L, Santaroni P. 1998. Mercury in Italy: from 9 environment to man, from pregnant women to newborns. La Rivista di Scienza 10 dell'Alimentazione 27:231-235.

11 Benson WW, Gabica J. 1972. Total mercury in hair from 1,000 Idaho residents-1971. 12 Pesticides Monitoring Journal 6:80-83.

13 Berglund M, Lind B, Björnberg KA, Palm B, Einarsson Ö, Vahter M. 2005. Inter-individual 14 variations of human mercury exposure biomarkers: a cross-sectional assessment. 15 Enviornmental Health 4:20.

16 Bolletta G. 1996. Il mercurio nel pescato del medio Adriatico. Industrie Alimentari 35:357$17360,367$.

18 Bruhn CG, Rodriguez AA, Barrios C, Jaramillo VH, Becerra J, Gonzales U, Gras NT, Reyes 19 O, Seremi-Salud. 1994. Determination of total mercury in scalp hair of pregnant and nursing 20 women resident in fishing villages in the Eighth Region of Chile. Journal of Trace Elements 21 and Electrolytes in Health and Disease 8:79-86.

22 Bryler-Iskane-Sheladia. 1994. Shema directeur d'assainissement liquide de Tetouan, Rapport 23 No. 2: programme de contrôle de pollution. [Technical report, in French]. Tetouan: Minister 24 of the Interior, Department of Local Communities.

25 Budtz-Jørgensen E, Grandjean P, Jørgensen PJ, Weihe P, Keiding N. 2004. Association 26 between mercury concentrations in blood and hair in methylmercury-exposed subjects at 27 different ages. Environmental Research 95:385-393. 
1 Bulinski R, Dabrowska D, Koktysz N, Kot A, Kotulas K, Michniewski J, Szydlowska E. 2 1979. Studies on the mercury content in human tissues from the general population of the 3 province of Lublin. Bromatologia i Chemia Toksykologiczna 12:67-70.

4 Buzina R, Stegnar P, Buzina-Suboticanec K, Horvat M, Petric I, Farley TMM. 1995. Dietary 5 mercury intake and human exposure in an Adriatic population. The Science of the Total 6 Environment 170:199-208.

7 Buzina R, Suboticanec K, Vukusic J, Sapunar J, Antonic K, Zorica M. 1989. Effect of 8 industrial pollution on seafood content and dietary intake of the total and methylmercury. The 9 Science of the Total Environment 78:45-57.

10 Cannizzaro C, Madarena G, Dazzi G, Chizzolini R, Campanini G. 1986. Livelli di mercurio e 11 di selenio nei prodotti della pesca provenienti dal porto di Pescara. Annali della Facoltà di 12 Medicina Veterinaria dell’Università di Parma 6:187-204.

13 Capelli R, Minganti V, de Pellegrini R. 1991. Determination of mercury (total and organic) 14 and selenium in seafood from the Ligurian sea for the study of the correlation $\mathrm{Hg}$ total/ $\mathrm{Hg}$ 15 organic/Se. In: UNEP/FAO. Final Reports on research projects dealing with mercury, toxicity 16 and analytical techniques. MAP Technical Reports Series No. 51. Athens: UNEP. pp. 37-56.

17 Crisetig G, Poletti R, Viviani R. 1985. Toxic metal distribution in marine organisms from sea 18 area opposite the Po delta. Archivio Veterinario Italiano 36:65-68.

Del Prete U, Bolletta G. 1984. Sui livelli di contaminazione da metalli pesanti nel pescato del 20 medio Adriatico. Nuovi Annali di Igene e Microbiologia 35:443-449.

21 Dickman MD, Leung CKM, Leong MKH. 1998. Hong Kong male subfertility links to 22 mercury in human hair and fish. The Science of the Total Environment 214:165-174.

23 Dumont C, Girard M, Bellavance F, Noël F. 1998. Mercury levels in the Cree population of 24 James Bay, Quebec, from 1988 to 1993/94. Canadian Medical Association Journal 158:1439251445.

26 EFSA. 2004. Opinion of the Scientific Panel on Contaminants in the Food Chain on a request 27 from the Commission related to mercury and methylmercury in food. The EFSA Journal 34:12814. 
1 Focardi S, Fossi C, Leonzio C, Marsili L, Mattei N. 1991. Idrocarburi clorurati e metalli 2 pesanti in varie specie ittiche del delta del Po. In: Atti del convegno "La Qualità delle Acque 3 del Fiume Po negli Anni '90", Quaderni IRSA 92:SP/21.1-SP/21.8.

4 Froese R, Pauly D. Editors. 2006 FishBase, version (07/2006) [Internet]. World Wide Web 5 electronic publication. Available from: www.fishbase.org.

6 Gårdfeldt K, Sommar J, Ferrara R, Ceccarini C, Lanzillotta E, Munthe J, Wångberg I, 7 Lindqvist O, Pirrone N, Sprovieri F, Pesenti E, Stråmberg D. 2003. Evasion of mercury from 8 coastal and open waters of the Atlantic Ocean and the Mediterranean Sea. Atmospheric 9 Environment 37 Supplement 1:S73-S84.

10 Gibičar D, Horvat M, Nakou S, Sarafidou J, Yager J. 2006. Pilot study of intrauterine 11 exposure to methylmercury in Eastern Aegean islands, Greece. The Science of the Total 12 Environment 367:586-595.

13 Horvat M, Zvonaric T, Stegnar P, Prosenc A, Konda D, Sabadin A. 1989. Relation between 14 total mercury, methylmercury and selenium in fish muscle from the Adriatic Sea. In: Vernet 15 J-P, editor. International Conference Heavy Metals in the Environment. Geneva: CEP 16 Consultants Ltd. pp. 370-373.

17 Hylander LD, Meili M. 2003. 500 years of mercury production: global annual inventory by 18 region until 2000 and associated emissions. The Science of the Total Environment 304:13-27.

19 Joiris CR, Holsbeek L, Laroussi Moatemri N. 1999. Total and Methylmercury in Sardines 20 (Sardinella aurita and Sardina pilchardus) from Tunisia. Marine Pollution Bulletin 38:188$21 \quad 192$.

22 Lee WC, Lee MJ. 1999. Mercury concentrations in scalp hair as an environmental 23 contamination index from foods in Korea. Veterinary and Human Toxicology 41:373-375.

24 Lindberg A, Bjornberg KA, Vahter M, Berglund M. 2004. Exposure to methylmercury in 25 non-fish-eating people in Sweden. Environmental Research 96:28-33.

26 Mikac N, Picer M. 1985. Mercury distribution in a polluted marine area. Concentrations of 27 methyl mercury in sediments and some marine organims. The Science of the Total 28 Environment 43:27-39. 
1 Moretti G., Bortoli A., Marin V., Ravazzolo E. 1995. Mercury levels in fisherman groups of 2 the North Adriatic sea. In: UNEP/WHO. Epidemiological studies related to the environmental 3 quality criteria for bathing waters, shellfish-growing waters and edible marine organisms.

4 MAP Technical Reports Series No. 93. Athens: UNEP. pp. 67-82.

5 Muir D, Braune B, DeMarch B, Norstrom R, Wagemann R, Lockhart L, Hargrave B, Bright 6 D, Addison R, Payne J, Reimer K. 1999. Spatial and temporal trends and effects of 7 contaminants in the Canadian Arctic marine ecosystem: a review. The Science of the Total 8 Environment 230:83-144.

9 Nakagawa R. 1995. Concentration of mercury in hair of diseased people in Japan. 10 Chemosphere 30:135-140.

11 NRC. 2000. Toxicological effects of methylmercury. Committee on the Toxicological Effects 12 of methylmercury, Board on Environmental Studies and Toxicology, Commission of Life 13 Sciences, National Research Council. Washington, DC: National Academy Press.

14 Paccagnella B, Prati L, Bigoni A. 1973. Studio epidemiologico sul mercurio nei pesci e la 15 salute umana in un'isola italiana del Mediterraneo. L'Igiene Moderna 66:479-503.

16 Pastor F, Hernández M, Peris A, Beltrán J, Sancho JV, Castillo MT. 1994. Levels of heavy 17 metals in some marine organisms from the western Mediterranean area (Spain). Marine 18 Pollution Bulletin 28:50-53.

19 Pellizzari ED, Fernando R, Cramer GM, Meaburn GM, Bangerter K. 1999. Analysis of 20 mercury in hair of EPA region $\mathrm{V}$ population. Journal of Exposure Analysis and 21 Environmental Epidemiology 9:393-401.

22 Pirrone N, Costa P, Pacyna JM, Ferrara R. 2001. Mercury emissions to the atmosphere from 23 natural and anthropogenic sources in the Mediterranean region. Atmospheric Environment 24 35:2997-3006.

25 Renzoni A, Zino F, Franchi E. 1998. Mercury levels along the food chain and risk for exposed 26 populations. Environmental Research A 77:68-72. 
1 Serrano R, Hernández F, López FJ. 1994. Trends in the bioavailability of heavy metals and 2 variations of fish catches in the western Mediterranean Sea (Castellon coast, Spain).

3 Toxicological and Environmental Chemistry 42:215-226.

4 Sivalingam PM, Binti Sani A. 1980. Mercury content in hair from fishing communities of the 5 State of Penang, Malaysia. Marine Pollution Bulletin 11:188-191.

6 Storelli MM, Giacominelli-Stuffler R, Storelli A, D'Addabbo R, Palermo C, Marcotrigiano 7 GO. 2003. Survey of total mercury and methylmercury levels in edible fish from the Adriatic 8 Sea. Food Additives and Contaminants 20:1114-1119.

9 Storelli MM, Storelli A, Giacominelli-Stuffler R, Marcotrigiano GO. 2005. Mercury 10 speciation in the muscle of two commercially important fish, hake (Merluccius merluccius) 11 and striped mullet (Mullus barbatus) from the Mediterranean sea: estimated weekly intake. 12 Food Chemistry 89:295-300.

13 Sumino K, Hayakawa K, Shibata T, Kitamura S. 1975. Heavy metals in normal Japanese 14 tissues - Amounts of 15 heavy metals in 30 subjects. Archives of Environmental Health $15 \quad 30: 487-494$.

16 Suzuki T, Takemoto T, Kashiwazaki H, Togo M, Toyokawa H, Miyama T. 1976. Man, fish 17 and mercury on small islands in Japan. Tohoku Journal of Experimental Medicine 118:18118198.

19 Thibaud Y, Noel J. 1991. Evaluation des teneurs en mercure, méthylmercure et selenium dans 20 les poissons et coquillages des côtes françaises de la Méditeranée. In: UNEP/FAO. Final 21 Reports on research projects dealing with mercury, toxicity and analytical techniques. MAP 22 Technical Reports Series No. 51. Athens: UNEP. pp. 1-18.

23 UNEP/FAO/WHO. 1987. Assessment of the state of pollution of the Mediterranean Sea by 24 mercury and mercury compounds. MAP Technical Reports Series No. 18. Athens: UNEP.

25 Valentino L, Torregrossa MV, Saliba LJ. 1995. Health effects of mercury ingested through 26 consumption of seafood. Water Science and Technology 32:41-47. 
1 Vukadin I, Zvonarić T, Odžak N. 1995. Fate and distribution of toxic heavy metals in some

2 marine organisms from the eastern Adriatic coast. Helgolander Meeresuntersuchungen $3 \quad 49: 679-688$.

4 WHO. 1990. Methylmercury. Environmental Health Criteria Volume 101. Geneva: World 5 Health Organization, International Programme on Chemical Safety.

6 WHO. 2000. Methylmercury. Prepared by the Fifty-third meeting of the Joint FAO/WHO 7 Expert Committee on Food Additives (JECFA). WHO Food Additives Series 44. Geneva: 8 World Health Organization, International Programme on Chemical Safety.

9 WHO. 2004. Methylmercury. Prepared by the Sixty-first meeting of the Joint FAO/WHO 10 Expert Committee on Food Additives (JECFA). WHO Food Additives Series 52. Geneva: 11 World Health Organization, International Programme on Chemical Safety.

12 Wolfram LJ. 2003. Human hair: a unique physicochemical composite. Journal of the 13 American Academy of Dermatology 48:S106-S114.

14 Working group on mercury. 2001. Ambient Air Pollution by Mercury (Hg) - Position Paper. 15 Luxembourg: Office for Official Publications of the European Communities. Available at: 16 http://europa.eu.int/comm/environment/air/background.htm\#mercury. 
1 Table I. Sociodemographic characteristics of the sample population

\begin{tabular}{lc}
\hline Sample description & \\
\hline Age & 34 \\
Mean (years) & $10-61$ \\
Range (years) & 19 \\
$10-19(\%)$ & 27 \\
$20-29(\%)$ & 19 \\
$30-39(\%)$ & 19 \\
$40-49(\%)$ & 16 \\
$>50(\%)$ & \\
Occupation & 25 \\
Fishermen and their families $(\%)$ & 21 \\
Farmers and their families $(\%)$ & 28 \\
Other occupations/No occupation $(\%)$ & 26 \\
Students (\%) & \\
\hline
\end{tabular}


1 Table II. Descriptive statistics concerning hair mercury concentrations $(\mu \mathrm{g} / \mathrm{g})$

\begin{tabular}{|c|c|c|c|c|c|c|c|c|c|c|c|}
\hline \multirow{2}{*}{$\begin{array}{l}\text { Sample } \\
\text { description }\end{array}$} & \multirow{2}{*}{$\mathrm{N}$} & \multirow{2}{*}{ GM } & \multirow{2}{*}{$\mathrm{AM}$} & \multirow{2}{*}{ Min } & \multirow{2}{*}{ Max } & \multicolumn{6}{|c|}{ Percentile } \\
\hline & & & & & & 10th & 25th & 50th & 75 th & 90th & 95th \\
\hline All & 108 & 1.79 & 2.90 & 0.22 & 9.56 & 0.49 & 0.93 & 1.46 & 5.03 & 7.79 & 8.85 \\
\hline Male & 68 & 2.07 & 3.25 & 0.29 & 9.56 & 0.53 & 1.14 & 1.71 & 5.75 & 8.63 & 9.28 \\
\hline Female & 40 & 1.40 & 2.29 & 0.22 & 7.88 & 0.35 & 0.71 & 1.18 & 3.82 & 5.59 & 6.30 \\
\hline Fish consumers ${ }^{a}$ & 65 & 1.04 & 1.21 & 0.29 & 3.56 & 0.49 & 0.75 & 1.16 & 1.46 & 1.99 & 2.33 \\
\hline Heavy fish consumers ${ }^{b}$ & 39 & 5.30 & 5.97 & 1.38 & 9.56 & 1.97 & 4.72 & 6.22 & 8.07 & 9.25 & 9.42 \\
\hline
\end{tabular}

$2{ }^{a}$ Subjects with a FCF of 1-2 times per week

$3{ }^{b}$ Subjects with a FCF of 3-5 times per week 
1 Table III. Hair mercury regression models

\begin{tabular}{|c|c|c|c|c|c|}
\hline & Standardiz & fficients & Non stan & ed coe & \\
\hline & Beta & $\mathrm{SE}^{a}$ & $B$ & $\mathrm{SE}^{a}$ & $p$-level \\
\hline $\begin{array}{l}\text { Model } 1 \text { (All subje } \\
\mathrm{R}^{2}=0.862\end{array}$ & & & & & \\
\hline Intercept & & & 0.059 & 0.020 & 0.003 \\
\hline Fish consumption & 0.929 & 0.036 & 0.199 & 0.008 & $<0.001$ \\
\hline $\begin{array}{l}\text { Model } 2 \text { (All subje } \\
\mathrm{R}^{2}=0.878\end{array}$ & & & & & \\
\hline Intercept & & & -0.065 & 0.041 & 0.111 \\
\hline Gender & 0.080 & 0.036 & 0.047 & 0.021 & 0.028 \\
\hline Age & 0.088 & 0.035 & 0.002 & 0.001 & 0.013 \\
\hline Fish consumption & 0.946 & 0.036 & 0.203 & 0.008 & $<0.001$ \\
\hline $\begin{array}{l}\text { Model } 3 \text { (Males) } \\
\mathrm{R}^{2}=0.877\end{array}$ & & & & & \\
\hline Intercept & & & -0.033 & 0.035 & 0.002 \\
\hline Age & 0.142 & 0.044 & 0.003 & 0.001 & 0.002 \\
\hline Fish consumption & 0.902 & 0.044 & 0.194 & 0.009 & $<0.001$ \\
\hline $\begin{array}{l}\text { Model } 4 \text { (Females } \\
\mathrm{R}^{2}=0.889\end{array}$ & & & & & \\
\hline Intercept & & & 0.058 & 0.026 & 0.029 \\
\hline Fish consumption & 0.943 & 0.054 & 0.219 & 0.013 & $<0.001$ \\
\hline
\end{tabular}

$2{ }^{a}$ Standard Error 
1 Table IV. Mercury concentration in muscle tissue of the fish most commonly consumed by 2 the population of Martil

\begin{tabular}{lcccc}
\hline Fish species & $n$ & Length $(\mathrm{cm})$ & \multicolumn{2}{c}{ Hg concentration $(\mu \mathrm{g} / \mathrm{g})$} \\
& & & Mean \pm S.D. & Range \\
\hline Pilchard (Sardina pilchardus) & 26 & $10-14$ & $0.137 \pm 0.042$ & $0.087-0.175$ \\
Common mullet (Mugil cephalus) & 24 & $20-25$ & $0.096 \pm 0.017$ & $0.091-0.115$ \\
Hake (Merluccius merluccius) & 18 & $20-38$ & $0.101 \pm 0.031$ & $0.081-0.124$ \\
\hline
\end{tabular}


1

3

4

5

6

7

8

9

10

11

12

13

14

15

16

17

18

19

20

21

22

23

24

25

26

27

28

29

30

31

32

33

34

35

36

37

38

39

40

41

42

43

44

45

46

47

48

49

50

51

52

53

54

55

56

57

58

59

60

1 Table V. Estimated weekly intake of mercury by the target population through fish

2 consumption and related biomarker data

\begin{tabular}{cccc}
\hline $\begin{array}{c}\text { Consumption frequency } \\
\text { Times/week }\end{array}$ & $\begin{array}{c}\text { Estimated Intake }^{a} \\
\mu \mathrm{g}\end{array}$ & $\begin{array}{c}\mathrm{Hg} \mathrm{hair}{ }_{\text {Obs }}^{b} \\
\mu \mathrm{g} / \mathrm{g}\end{array}$ & $\begin{array}{c}\mathrm{Hg} \mathrm{hair}_{\text {Reg }}{ }^{c} \\
\mu \mathrm{g} / \mathrm{g}\end{array}$ \\
\hline 0 & 0 & 0.29 & 0.15 \\
1 & 20 & 1.04 & 0.81 \\
2 & 40 & 1.70 & 1.86 \\
3 & 60 & 3.69 & 3.53 \\
4 & 80 & 6.68 & 6.16 \\
5 & 100 & 9.23 & 10.32 \\
\hline
\end{tabular}

3 Assumptions: $\mathrm{Hg}$ concentration in fish equal to the average of concentrations found in the most

4 consumed species $(0.111 \mu \mathrm{g} / \mathrm{g}), 90 \%$ of mercury in fish is methylmercury

$5 \quad{ }^{b}$ Observed mercury concentration in hair samples (GM)

$6 \quad{ }^{c}$ Hair mercury concentration obtained through regression model 1 
Table VI. Hair mercury concentrations found in surveys concerning Mediterranean populations $(\mu \mathrm{g} / \mathrm{g})$

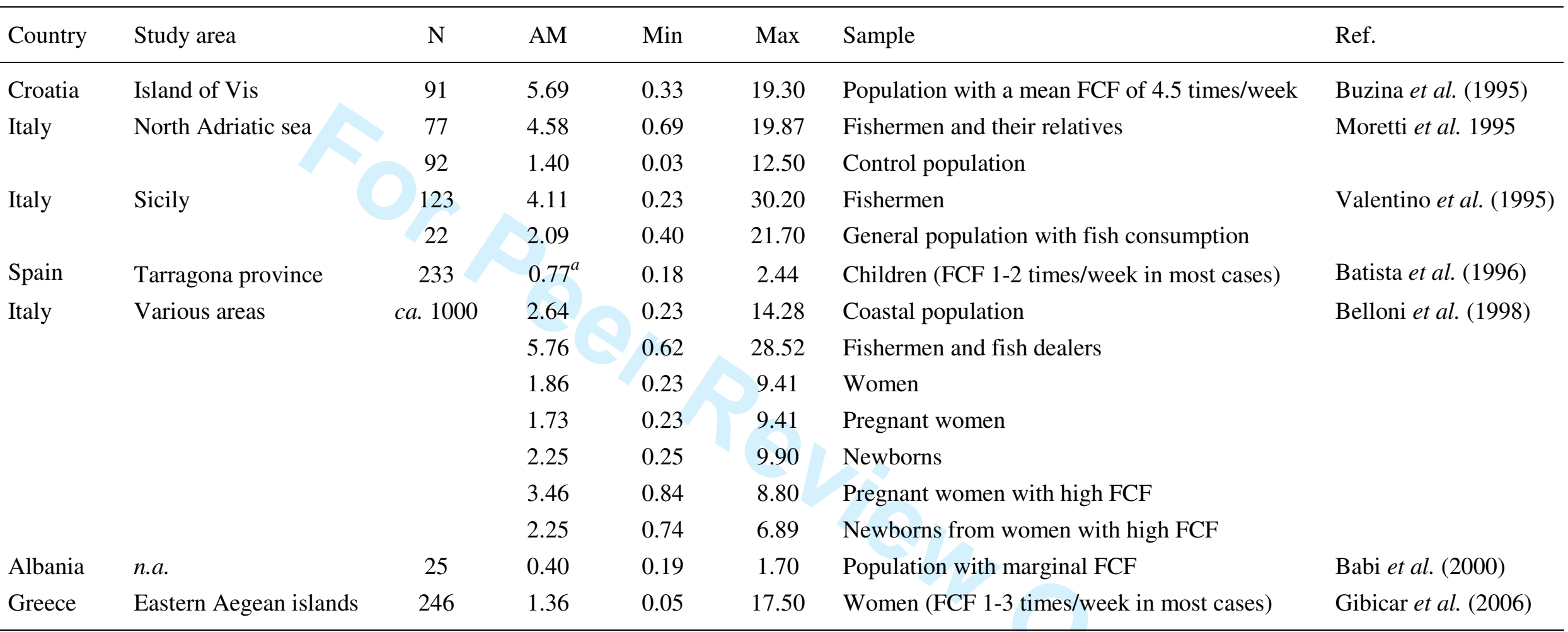

${ }^{a} \mathrm{GM}$ 
Figure 1. Map of the study area
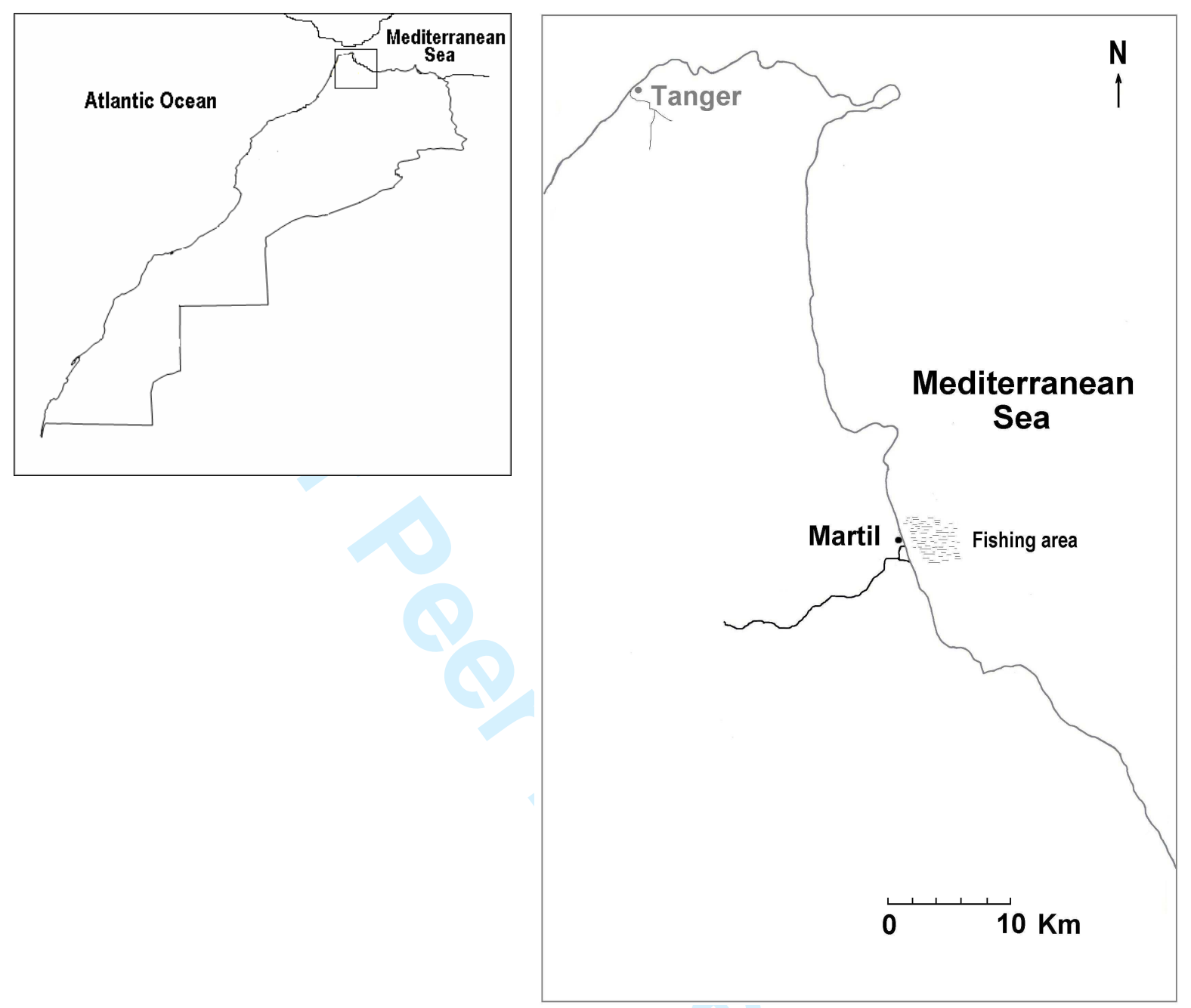
Figure 2. Plot of hair mercury concentrations versus FCF (untransformed data).

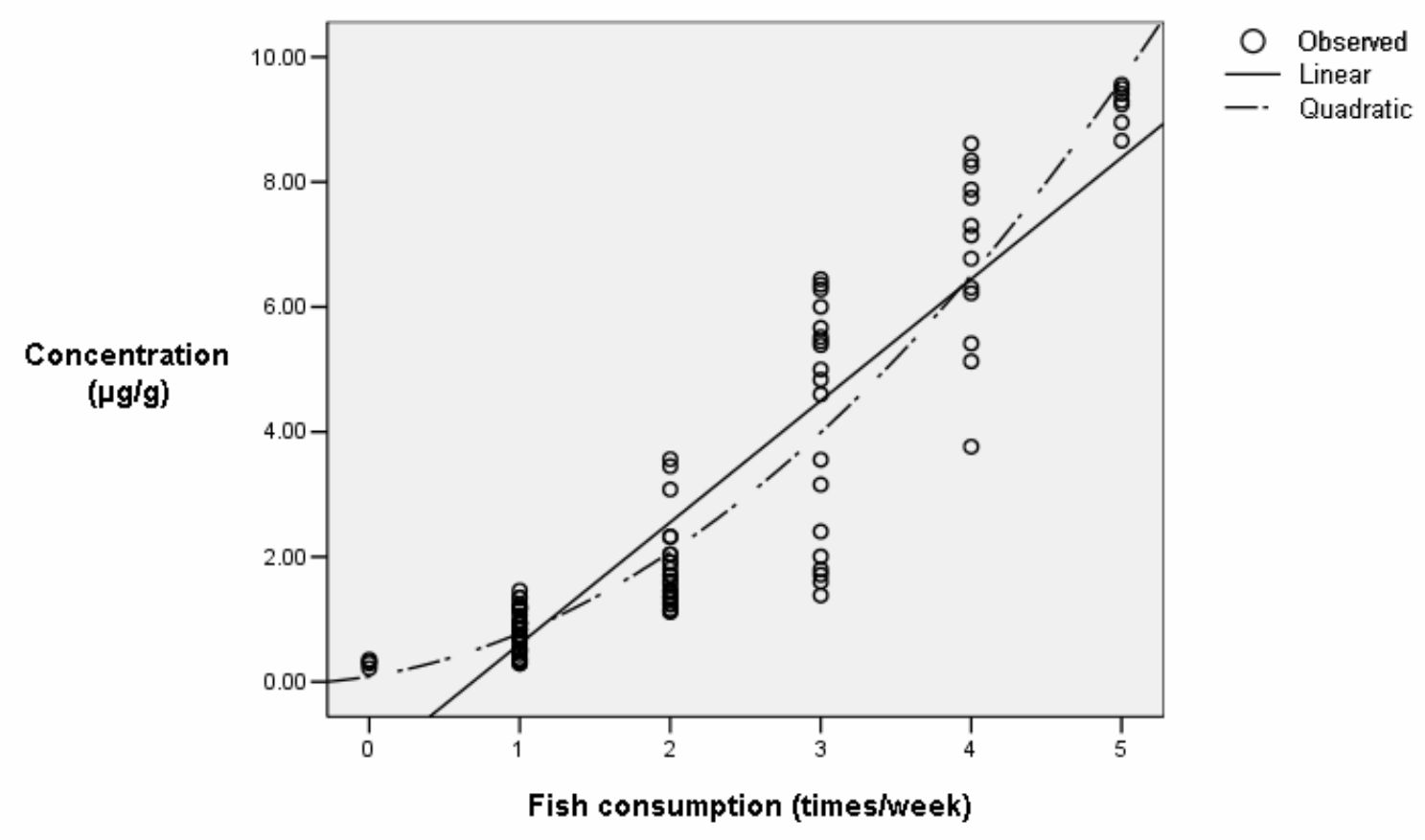


Figure 3. Hair mercury concentrations in different age groups of male and female subjects with a FCF of 1 time per week (GMs in $\mu \mathrm{g} / \mathrm{g}$ and their 95\%C.I.).

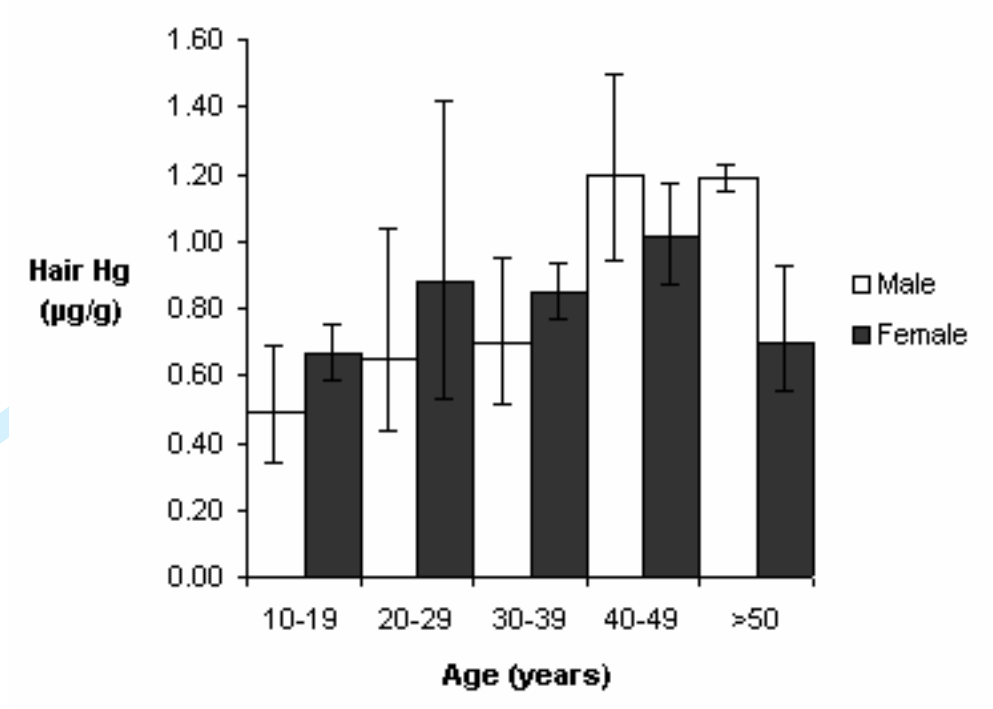

